\title{
Detrimental effects of verapamil in patients with primary pulmonary hypertension
}

\author{
MILTON PACKER, NORMA MEDINA, MADELINE YUSHAK, ISAAC WIENER \\ From the Division of Cardiology, Department of Medicine, Mount Sinai School of Medicine of the City University of \\ New York, New York, USA
}

SUMmary Calcium channel blockade provides a logical approach to the treatment of pulmonary hypertension because these drugs exert direct vasodilator effects in the highly constricted pulmonary circulation. To determine the effectiveness of verapamil in the treatment of primary pulmonary hypertension the haemodynamic effects of the drug were evaluated in seven patients with this disorder; $10 \mathrm{mg}$ was given intravenously to six patients and $120 \mathrm{mg}$ orally to one patient. Verapamil produced a $20 \%$ decline in pulmonary vascular resistance and a $27 \%$ decrease in mean pulmonary arterial pressure without significant changes in systemic vascular resistance. One patient who received verapamil $480 \mathrm{mg}$ orally daily for three months showed sustained haemodynamic and clinical improvement. Concomitant with its beneficial effects on the pulmonary circulation, however, verapamil produced a pronounced decrease in right ventricular stroke work index (42\%) and increase in right ventricular filling pressure (50\%), indicating a direct depressant effect of the drug on right ventricular function. In one patient these cardiodepressant effects were sufficiently pronounced to produce severe hypotension and cardiac arrest.

In conclusion, although verapamil appears to exert preferential vasodilator effects on the pulmonary circulation, its negative inotropic effects may be particularly detrimental to patients with primary pulmonary hypertension who have pre-existing right ventricular dysfunction; hence, treatment with verapamil is not recommended in such cases.

Because pulmonary vasoconstriction has been thought to play an important contributory role in the pathophysiology of primary pulmonary hypertension $^{1-3}$ several vasodilator drugs have been used in patients with this disorder in an attempt to reduce pulmonary artery pressure and pulmonary vascular resistance. ${ }^{4}$ Although occasionally haemodynamic and clinical benefit have followed treatment with various vasodilator agents, ${ }^{4-7}$ there remains no satisfactory pharmacological approach to the management of these patients. The major limitation to presently available drugs is that most agents have potent systemic vasodilator effects that exceed the magnitude of their effects on the pulmonary circulation; these systemic effects may result in severe hypotension before any appreciable improvement in pulmonary haemodynamic indices occurs. ${ }^{489}$

Requests for reprints to Dr Milton Packer, Division of Cardiology, Mount Sinai Medical Center, 1 Gustave Levy Place, New York, New York 10029, USA.

Accepted for publication 1 March 1984
Because calcium appears to play a critical role in vascular smooth muscle contraction ${ }^{1011}$ calcium channel blockade with nifedipine and verapamil provides a logical approach to the treatment of a variety of conditions characterised by abnormal regional vasoconstriction. ${ }^{12-15}$ Calcium channel antagonists appear to exert preferential effects in regional vascular systems that are highly constricted, particularly in the coronary, cerebral, and pulmonary circulations ${ }^{1016}$; hence, these drugs have proved useful in the treatment of vasospastic angina and in subarachnoid haemorrhage ${ }^{12-14}$; however, there are only preliminary data on the usefulness of calcium channel blockade in pulmonary vasoconstrictive states. Nifedipine attenuates the vasoconstrictor response to hypoxia in several experimental preparations ${ }^{17} 18$ and in patients with acute respiratory failure, ${ }^{19}$ and several case studies have reported the benefits of short and long term nifedipine treatment in patients with primary pulmonary hypertension. ${ }^{20-24}$ In contrast, although verapamil also attenuates hypoxic pulmonary vasoconstriction 182526 there are few data on its effective- 
ness in hypoxic or primary pulmonary hypertension. ${ }^{27}$ The therapeutic application of verapamil in the treatment of abnormal pulmonary vasoconstriction has theoretical appeal since the drug exerts less pronounced effects on the systemic circulation than does nifedipine ${ }^{11}$ and thus may produce less hypotension than do drugs that have pronounced systemic vasodilator actions.

In the present study we evaluated the haemodynamic and clinical responses to verapamil in seven patients with primary pulmonary hypertension, one of whom was treated with the drug for three months and underwent repeat haemodynamic evaluation.

\section{Patients and methods}

\section{STUDY POPULATION}

We studied seven patients with primary pulmonary hypertension (five women, two men; age range 28-64 (mean 48) years). The diagnosis was established in all patients by right heart catheterisation, which confirmed the pronounced increase in pulmonary artery pressures (mean pulmonary artery pressure $>30 \mathrm{~mm} \mathrm{Hg}$ ) and a normal pulmonary capillary wedge pressure $(<15 \mathrm{~mm} \mathrm{Hg}$ ). Gated equilibrium scintigraphy showed normal left ventricular function and moderately to severely impaired right ventricular function. All patients has normal ventilationperfusion scans and normal pulmonary function tests; the diagnosis was confirmed by pulmonary angiography or open lung biopsy or both. All patients had dyspnoea and fatigue on minimal or moderate exertion, but their condition was clinically stable at the time of evaluation.

\section{HAEMODYNAMIC MEASUREMENTS}

After all medications had been withheld for at least 12 hours right heart catheterisation was performed with a triple lumen, flow directed catheter for measuring right heart pressures, and cannulation of the radial artery used for measuring systemic arterial pressures. Haemodynamic measurements were made with the zero reference level at the midaxillary line with the patient supine. Left ventricular filling pressure was measured as the mean pulmonary capillary wedge pressure. Cardiac output was determined by the thermodilution method with a bedside cardiac output computer after injection of iced saline solution. Heart rates were derived from a continuously recorded electrocardiogram. All patients were breathing room air throughout the study.

\section{DRUG ADMINISTRATION}

Before drug administration mean systemic arterial pressure, heart rate, mean pulmonary capillary wedge pressure, mean right atrial pressure, and cardiac output were measured repeatedly (with a variation of $<10 \%$ ) until a stable haemodynamic state was achieved. Six patients then received $5 \mathrm{mg}$ of verapamil intravenously followed by a additional $5 \mathrm{mg}$ intravenously 10 minutes later; haemodynamic indices were measured every five minutes for $\mathbf{3 0}$ minutes after drug administration. One patient received a single dose of $120 \mathrm{mg}$ of verapamil orally, after which haemodynamic indices were measured every 30 minutes for three hours.

After completion of the intravenous study, long term treatment with oral verapamil ( $480 \mathrm{mg}$ daily) was started in one patient, who underwent repeat haemodynamic evaluation after three months; at that time, the haemodynamic effects of verapamil were assessed at peak drug effect, and 48 hours after drug withdrawal. This patient received no other medications during this period.

\section{DATA ANALYSIS}

Mean systemic and pulmonary artery pressures were determined by electronic filtration. Derived haemodynamic variables were calculated according to the following formulae: cardiac index $(\mathrm{CI})=\mathrm{CO} /$ body surface area $\left(1 / \mathrm{min} / \mathrm{m}^{2}\right)$; stroke volume index $(\mathrm{SVI})=$ $\mathrm{CI} / \mathrm{HR}\left(\mathrm{ml} / \mathrm{beat} / \mathrm{m}^{2}\right) ; \mathrm{RV}$ stroke work index (RVSWI) $=$ SVI $\times 0.0136 \times($ MPAP-MRAP $)\left(\mathrm{g} \mathrm{m} / \mathrm{m}^{2}\right) ;$ systemic vascular resistance (SVR) = $80 \times(\mathrm{MAP}-\mathrm{MRAP}) / \mathrm{CO}$ (dyn s cm$\left.{ }^{-5}\right)$; and pulmonary vascular resistance (PVR) = $80 \times(\mathrm{MPAP}-\mathrm{PCW}) / \mathrm{CO}\left(\right.$ dyn s cm $\left.\mathrm{cm}^{-5}\right)$, where $\mathrm{CO}$ is cardiac output, HR heart rate, MAP mean systemic arterial pressure, PCW pulmonary capillary wedge pressure, MPAP mean pulmonary artery pressure, MRAP mean right atrial pressure, and RV right ventricular.

The responses to verapamil at peak drug effect were compared with control values by the $t$ test for paired data. Group data were expressed as mean (1 SD).

\section{Results}

\section{HAEMODYNAMIC EFFECTS}

The individual haemodynamic responses to verapamil in the seven patients with primary pulmonary hypertension are shown in Table 1. Verapamil produced a decrease in pulmonary vascular resistance in each patient in our study (range 10-32\%); overall, mean pulmonary vascular resistance declined from 1344 to 1078 dyn s cm ${ }^{-5}(p<0.025)$. In contrast, the small decrease in systemic vascular resistance after verapamil (1619 to 1469 dyn s cm$~_{-5}$ ) was not significant, and the decline in pulmonary vascular resistance exceeded the changes seen in the systemic circulation in all but one patient. 
Table 1 Individual haemodynamic responses to verapamil in patients with primary pulmonary hypertension

\begin{tabular}{|c|c|c|c|c|c|c|c|c|c|}
\hline \multirow[t]{2}{*}{ Haemodynamic index } & \multicolumn{7}{|c|}{ Case Nos } & \multirow{2}{*}{$\begin{array}{l}\text { Mean }(S D) \\
\text { oalue }\end{array}$} & \multirow[t]{2}{*}{ p value } \\
\hline & 1 & 2 & 3 & 4 & 5 & 6 & 7 & & \\
\hline $\begin{array}{l}\text { Mean arterial pressure }(\mathrm{mm} \mathrm{Hg}) \\
\text { Control } \\
\text { Verapamil } \\
\text { Heart rate (beats/min) }\end{array}$ & $\begin{array}{l}82 \\
69\end{array}$ & $\begin{array}{l}114 \\
109\end{array}$ & 102 & $\begin{array}{l}85 \\
76\end{array}$ & $\begin{array}{l}65 \\
56\end{array}$ & $\begin{array}{l}69 \\
50\end{array}$ & $\begin{array}{l}79 \\
73\end{array}$ & $\begin{array}{l}85 \cdot 1(17 \cdot 5) \\
72 \cdot 6(18 \cdot 9)\end{array}$ & $<0.01$ \\
\hline $\begin{array}{l}\text { Control } \\
\text { Verapamil } \\
\text { Mean pulmonary artery pressure }(\mathrm{mm} \mathrm{Hg})\end{array}$ & $\begin{array}{l}104 \\
100\end{array}$ & $\begin{array}{l}79 \\
89\end{array}$ & $\begin{array}{l}95 \\
90\end{array}$ & $\begin{array}{l}79 \\
81\end{array}$ & $\begin{array}{l}90 \\
67\end{array}$ & $\begin{array}{l}109 \\
95\end{array}$ & $\begin{array}{l}103 \\
89\end{array}$ & $\begin{array}{l}94 \cdot 1(12 \cdot 1) \\
87.3(10.7)\end{array}$ & NS \\
\hline $\begin{array}{l}\text { Control } \\
\text { Verapamil } \\
\text { Pulmonary capillary wedge pressure (mm Hg) }\end{array}$ & $\begin{array}{l}60 \\
38\end{array}$ & $\begin{array}{l}61 \\
56\end{array}$ & $\begin{array}{l}121 \\
66\end{array}$ & $\begin{array}{l}68 \\
53\end{array}$ & $\begin{array}{l}42 \\
35\end{array}$ & $\begin{array}{l}41 \\
33\end{array}$ & $\begin{array}{l}50 \\
42\end{array}$ & $\begin{array}{l}63 \cdot 3(27 \cdot 4) \\
46 \cdot 1(12 \cdot 4)\end{array}$ & $<0.05$ \\
\hline $\begin{array}{l}\text { Control } \\
\text { Verapamil }\end{array}$ & $\begin{array}{l}7 \\
13\end{array}$ & $\begin{array}{l}12 \\
12\end{array}$ & $\begin{array}{l}14 \\
16\end{array}$ & $\begin{array}{l}6 \\
8\end{array}$ & $\begin{array}{l}10 \\
13\end{array}$ & $\begin{array}{l}2 \\
2\end{array}$ & $\begin{array}{l}2 \\
4\end{array}$ & $\begin{array}{l}7.6(4.7) \\
9.7(5.2)\end{array}$ & $<0.05$ \\
\hline $\begin{array}{l}\text { Mean right atrial pressure }(\mathrm{mm} \mathrm{Hg}) \\
\text { Control } \\
\text { Verapamil }\end{array}$ & $\begin{array}{l}10 \\
23\end{array}$ & $\begin{array}{l}14 \\
18\end{array}$ & $\begin{array}{l}19 \\
26\end{array}$ & $\begin{array}{l}5 \\
9\end{array}$ & $\begin{array}{l}11 \\
16\end{array}$ & $\begin{array}{l}17 \\
23\end{array}$ & $\begin{array}{l}4 \\
5\end{array}$ & $\begin{array}{l}11.4(5.7) \\
17.1(7.8)\end{array}$ & $<0.01$ \\
\hline $\begin{array}{l}\text { Cardiac index }\left(1 / \mathrm{min} / \mathrm{m}^{2}\right) \\
\text { Control } \\
\text { Verapamil }\end{array}$ & $\begin{array}{l}2.05 \\
1.23\end{array}$ & $\begin{array}{l}2.80 \\
2.77\end{array}$ & $\begin{array}{l}1.39 \\
0.81\end{array}$ & $\begin{array}{l}2.23 \\
2.38\end{array}$ & $\begin{array}{l}3.52 \\
3.24\end{array}$ & $\begin{array}{l}1.42 \\
1.37\end{array}$ & $\begin{array}{l}2.14 \\
1.90\end{array}$ & $\begin{array}{l}2.22(0.75) \\
1.96(0.88)\end{array}$ & NS \\
\hline $\begin{array}{l}\text { Stroke volume index }\left(\mathrm{ml} / \mathrm{beat} / \mathrm{m}^{2}\right) \\
\text { Control } \\
\text { Verapamil }\end{array}$ & $\begin{array}{l}19.7 \\
12 \cdot 3\end{array}$ & $\begin{array}{l}35 \cdot 4 \\
31 \cdot 1\end{array}$ & $\begin{array}{r}14.6 \\
9.0\end{array}$ & $\begin{array}{l}28 \cdot 2 \\
29.4\end{array}$ & $\begin{array}{l}39 \cdot 1 \\
48 \cdot 4\end{array}$ & $\begin{array}{l}13.0 \\
14.4\end{array}$ & $\begin{array}{l}20.8 \\
21.3\end{array}$ & $\begin{array}{l}24.4(10.1) \\
23.7(13.8)\end{array}$ & NS \\
\hline $\begin{array}{l}\text { Pulmonary vascular resistance (dyn } \mathrm{s} \mathrm{cm}^{-5} \text { ) } \\
\text { Control } \\
\text { Verapamil }\end{array}$ & $\begin{array}{l}1194 \\
939\end{array}$ & $\begin{array}{l}728 \\
658\end{array}$ & $\begin{array}{l}3658 \\
2920\end{array}$ & $\begin{array}{l}1046 \\
709\end{array}$ & $\begin{array}{l}488 \\
364\end{array}$ & $\begin{array}{l}1224 \\
1008\end{array}$ & $\begin{array}{l}1067 \\
950\end{array}$ & $\begin{array}{l}1344(1054) \\
1078(842)\end{array}$ & $<0.025$ \\
\hline $\begin{array}{l}\text { Systemic vascular resistance }\left(\text { dyn } \mathrm{s} \mathrm{cm}^{-5} \text { ) }\right. \\
\text { Control } \\
\text { Verapamil }\end{array}$ & $\begin{array}{l}1623 \\
1728\end{array}$ & $\begin{array}{l}1479 \\
1361\end{array}$ & $\begin{array}{l}2838 \\
2861\end{array}$ & $\begin{array}{l}1350 \\
1055\end{array}$ & $\begin{array}{l}808 \\
663\end{array}$ & $\begin{array}{l}1569 \\
915\end{array}$ & $\begin{array}{l}1667 \\
1700\end{array}$ & $\begin{array}{l}1619(611) \\
1469(730)\end{array}$ & NS \\
\hline $\begin{array}{l}\text { Right ventricular stroke work index }\left(\mathrm{g} \mathrm{m} / \mathrm{m}^{2}\right) \\
\text { Control } \\
\text { Verapamil }\end{array}$ & $\begin{array}{r}13.4 \\
2.5\end{array}$ & $\begin{array}{l}22.6 \\
16 \cdot 1\end{array}$ & $\begin{array}{r}20.3 \\
4.9\end{array}$ & $\begin{array}{l}24.2 \\
17.6\end{array}$ & $\begin{array}{l}16.5 \\
12.5\end{array}$ & $\begin{array}{l}4.2 \\
2.0\end{array}$ & $\begin{array}{l}13.0 \\
10.7\end{array}$ & $\begin{array}{l}16.3(6.9) \\
9.5(6.4)\end{array}$ & $<0.01$ \\
\hline
\end{tabular}

The fall in pulmonary vascular resistance after verapamil resulted primarily from a pronounced decrease in mean pulmonary artery pressure with the drug $(63.3$ to $46.1 \mathrm{~mm} \mathrm{Hg}, \mathrm{p}<0.05)$ since there was little overall change in cardiac index. Part of the lack of improvement in cardiac index occurred because heart rate decreased substantially in some patients ( $>10$ beats/min in three patients), but the overall fall in heart rate $(-7$ beats/min) was not significant, and thus, there were no overall changes in stroke volume index ( 24.4 to $\left.23.7 \mathrm{ml} / \mathrm{beat} / \mathrm{m}^{2}\right)$. Verapamil produced a significant increase in mean right atrial pressure (11.4 to $17.1 \mathrm{~mm} \mathrm{Hg}, \mathrm{p}<0.01)$, however, and a decrease in right ventricular stroke work index (16.3 to $\left.9.5 \mathrm{~g} \mathrm{~m} / \mathrm{m}^{2}, \mathrm{p}<0.01\right)$.

Although there were no overall changes in cardiac index, two patients had a pronounced decrease in cardiac index after verapamil $(-0.82$ and $-0.581 / \mathrm{min} /$ $\mathrm{m}^{2}$ ), and these two patients also showed the most pronounced changes in mean pulmonary artery pressure $(-22$ and $-55 \mathrm{~mm} \mathrm{Hg}$ ), mean right atrial pressure $(+13$ and $+7 \mathrm{~mm} \mathrm{Hg}$ ), and right ventricular stroke work index $\left(-10.9\right.$ and $-15.4 \mathrm{~g} \mathrm{~m} / \mathrm{m}^{2}$ respectively) seen in our seven patients.

Additional haemodynamic effects after verapamil administration included a moderate decrease in mean arterial pressure $(85.1$ to $72.6 \mathrm{~mm} \mathrm{Hg}, \mathrm{p}<0.01)$ and a small increase in pulmonary capillary wedge pressure ( 7.6 to $9.7 \mathrm{~mm} \mathrm{Hg}, \mathrm{p}<0.05$ ).

\section{CLINICAL EFFECTS}

Four patients tolerated intravenous verapamil well without adverse effects, but three patients experienced unfavourable clinical reactions. One patient had severe dyspnoea immediately after verapamil administration while systemic oxygen saturation decreased from 85 to $79 \%$, and she improved after receiving supplemental oxygen treatment. The one patient who showed a decrease in systemic vascular resistance that exceeded the fall in pulmonary vascular resistance experienced chest pain and dyspnoea as mean arterial pressure declined to $50 \mathrm{~mm} \mathrm{Hg}$; these effects were short lived, and the patient improved without specific treatment. In one of the two patients who had a pronounced decrease in cardiac index and right ventricular stroke work index intravenous verapamil administration rapidly produced hypotension, loss of consciousness, and cardiac arrest; the patient improved rapidly with cardiac compression and intravenous noradrenaline and calcium chloride administration.

One patient was treated with oral verapamil $120 \mathrm{mg}$ four times daily for three months (Table 2). After 48 hours verapamil produced a $26 \%$ increase in stroke volume index, a $36 \%$ decrease in mean pulmonary artery pressure, and a $37 \%$ decrease in pulmonary vascular resistance, compared with pretreatment values, with minimal change in systemic arterial pressure or systemic vascular resistance. After three months' 
Table 2 Short and long term haemodynamic effects of verapamil in a patient with primary pulmonary hypertension treated for three months

\begin{tabular}{|c|c|c|c|c|c|}
\hline \multirow[t]{2}{*}{ Haemodymamic index } & \multirow{2}{*}{$\begin{array}{l}\text { Control } \\
\text { values }\end{array}$} & \multicolumn{4}{|c|}{ Afier verapamil (mg) } \\
\hline & & $\begin{array}{l}120 \text { orally } \\
\text { (furst dose) }\end{array}$ & $\begin{array}{l}480 / d a y \\
\text { for } 48 h\end{array}$ & $\begin{array}{l}480 / d a y \\
\text { for } 3 \mathrm{~m}\end{array}$ & $\begin{array}{l}48 \text { h after } \\
\text { withdrawal }\end{array}$ \\
\hline 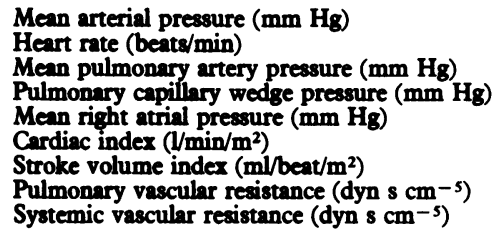 & $\begin{array}{l}79 \\
103 \\
50 \\
2 \\
4 \\
2 \cdot 14 \\
20.8 \\
1067 \\
1667\end{array}$ & $\begin{array}{l}73 \\
89 \\
42 \\
4 \\
5 \\
1 \cdot 90 \\
21 \cdot 3 \\
950 \\
1700\end{array}$ & $\begin{array}{l}73 \\
73 \\
32 \\
5 \\
9 \\
1 \cdot 91 \\
26 \cdot 2 \\
673 \\
1595\end{array}$ & $\begin{array}{l}79 \\
79 \\
44 \\
8 \\
9 \\
1.93 \\
24 \cdot 4 \\
889 \\
1728\end{array}$ & $\begin{array}{l}85 \\
99 \\
59 \\
3 \\
3 \\
2 \cdot 14 \\
21 \cdot 6 \\
1248 \\
1827\end{array}$ \\
\hline
\end{tabular}

treatment, the patient's dyspnoea and fatigue had moderately improved, and exercise duration on a bicycle ergometer $(150 \mathrm{kpm} / \mathrm{min}(24.5 \mathrm{~W})$ for three minutes followed by increments of $150 \mathrm{kpm} / \mathrm{min}$ (24.5 W) every three minutes until exhaustion) increased from 6.3 to 7.8 minutes. Repeat haemodynamic evaluation after three months' treatment and again 48 hours after withdrawal of verapamil showed sustained effects of the drug with decreases in mean pulmonary artery pressure and pulmonary vascular resistance similar to those during the start of treatment; however, there was evidence of mild progression of the underlying pulmonary vascular disease during the course of follow up.

\section{Discussion}

Calcium channel blockade provides a logical approach to the treatment of patients with pulmonary hypertension. In so far as vasoconstriction plays an important role in these patients and appears to be critically dependent on intracellular calcium, ${ }^{41011}$ calcium channel antagonism may serve to ameliorate the haemodynamic abnormalities and produce clinical benefits. This approach is of particular interest since calcium channel blocking drugs appear selectively to dilate constricted vessels ${ }^{16}$ and may exert preferential effects on the pulmonary circulation. ${ }^{10}$ Nifedipine attenuates hypoxic pulmonary vasoconstriction experimentally and clinically, ${ }^{17-19}$ and preliminary results with both short and long term treatment in patients with primary pulmonary hypertension have been highly favourable. ${ }^{20-24}$ Nevertheless, nifedipine exerts potent systemic vasodilator effects in addition to those in the pulmonary circulation, ${ }^{11}$ and this could lead to severe hypotension if the diseased pulmonary vascular bed is not responsive to calcium channel blockade. In addition, nifedipine may activate the sympathetic nervous system, ${ }^{28}$ which may exacerbate the pulmonary hypertension by increasing venous return to the right heart and by increasing right ventricular contractility. ${ }^{29}{ }^{30}$ Lastly, long term nifedipine treatment may be accompanied by peripheral oedema ${ }^{31}$; such fluid retention may confuse the clinical picture of right heart failure, which so commonly complicates the course of chronic pulmonary hypertension.

Verapamil may provide a therapeutic alternative to nifedipine for the management of pulmonary hypertension. Compared with nifedipine the drug appears to exert less pronounced effects on systemic vascular resistance, ${ }^{11}$ neutralises the reflex increase in sympathetic tone resulting from systemic vasodilatation, ${ }^{28}$ and rarely produces peripheral oedema. ${ }^{13}$ In a similar way to nifedipine, verapamil attenuates acute hypoxic pulmonary vasoconstriction in experimental studies 182526 and may lessen the magnitude of secondary right ventricular hypertrophy after chronic hypoxia. ${ }^{32} 33$ There are, however, few reports of the use of verapamil in hypoxic pulmonary hypertension in man. Furthermore, preliminary work by Landmark and colleagues ${ }^{27}$ with verapamil in nine patients with primary pulmonary hypertension has largely been unfavourable. These investigators found that the injection of $0.15 \mathrm{mg} / \mathrm{kg}$ of verapamil directly into the pulmonary artery produced only small decreases in pulmonary artery pressure and no change in pulmonary vascular resistance or cardiac output. Although an occasional patient showed notable pulmonary vasodilatation, others had pronounced decreases in cardiac output and right ventricular stroke work, one of whom had severe dyspnoea and hypotension after drug administration. Because of the lack of appreciable pulmonary vasodilator effects, Landmark et al doubted that long term verapamil treatment would be beneficial in patients with primary pulmonary hypertension.

Our results in seven patients with primary pulmonary hypertension extend the findings of Landmark et al. In contrast to these earlier observations, ${ }^{27}$ we found that verapamil produced significant decreases in pulmonary vascular resistance that exceeded those in systemic resistance; these favourable pulmonary vasodilator effects were accompanied by pronounced 
decreases in mean pulmonary artery pressure. Long term treatment with oral verapamil in one patient produced notable haemodynamic and symptomatic improvement that was sustained for three months. Unfortunately, despite these benefits, cardiac index failed to increase in most of our patients despite the decrease in resistance to right ventricular systolic ejection because verapamil treatment was accompanied by decreases in right ventricular stroke work and increases in right ventricular filling pressure; these haemodynamic responses indicated that the drug exerted a direct negative inotropic effect on right ventricular function, independent of its pulmonary vasodilator action. This is consistent with the known cardiodepressant effects of verapamil that result from its ability to block transmembrane calcium transport in the myocardium. ${ }^{34} 35$ Although such negative inotropic effects are usually offset by the drug's ability to reduce ventricular afterload, ${ }^{28}$ this neutralisation does not appear to be sufficient in patients with compromised ventricular function, who are particularly sensitive to verapamil's negative inotropic action ${ }^{35}$; this may be especially true if the degree of pulmonary vasodilatation is limited by obliterative pulmonary vascular disease. ${ }^{8}$ Hence, in our patients with a severely reduced right ventricular ejection fraction due to chronic pressure overload, right ventricular performance deteriorated after verapamil treatment. Two of the seven patients showed pronounced cardiodepressant effects, one of whom experienced cardiogenic shock and arrest, which required the intravenous administration of pressors and calcium chloride to restore circulatory homeostasis. Although the clinical importance of the negative inotropic effects of verapamil in patients with pre-existing left ventricular dysfunction is well established, ${ }^{35}$ this is the first report to document the potential dangers of verapamil in patients with underlying right ventricular failure.

Two other patients experienced adverse reactions with intravenous verapamil that were not related to the drug's negative inotropic action. One patient, who showed pronounced systemic vasodilator effects but minimal effects on the pulmonary circulation, experienced severe hypotension associated with chest pain and dyspnoea after receiving verapamil. Another patient had severe dyspnoea associated with a pronounced decrease in systemic oxygen saturation (to $79 \%)$. Both reactions have been seen with other vasodilator drugs in patients with pulmonary hyperten$\operatorname{sion}^{819}$ and appear to be secondary to the pronounced systemic vasodilator effects that may occasionally accompany treatment (and produce hypotension) and to the dilatation of transpulmonary shunts (which may produce hypoxaemia). ${ }^{78}$

In conclusion, despite its preferential vasodilator effects on the pulmonary circulation, we do not recommend verapamil for treating patients with primary pulmonary hypertension. Although an occasional patient's condition may improve during short and long term treatment with the drug, most patients will experience major depressant effects on right ventricular performance, and this may have serious cardiovascular consequences. Calcium channel blockade may be a useful approach to the management of primary pulmonary hypertension, but its application requires the development of a drug with selective pulmonary vasodilator effects and without appreciable negative inotropic action. Since verapamil may be given to patients with chronic pulmonary hypertension for the treatment of atrial tachycardias (in patients with severe mitral stenosis) or for the treatment of exertional angina (in patients with chronic obstructive lung disease), we advise caution with its use in any patient with severe right ventricular dysfunction.

MP is the recipient of a Young Investigator's Research Award from the National Heart, Lung and Blood Institute, Bethesda, Maryland, USA.

\section{References}

1 Dresdale DT, Michtom RJ, Schultz M. Recent studies in primary pulmonary hypertension including pharmacodynamic observations on pulmonary vascular resistance. Bull NY Acad Med 1954; 30: 195-207.

2 Wagenvoort CA, Wagenvoort N. Primary pulmonary hypertension. A pathologic study of the lung vessels in 156 clinically diagnosed cases. Calculation 1970; 42: 1163-84.

3 Reeves JT, Noonan JA. Microarteriographic studies of primary pulmonary hypertension. Arch Pathol 1973; 95: 50-5.

4 Rich S, Martinez J, Lam W, Levy PS, Rosen KM. Reassessment of the effects of vasodilator drugs in primary pulmonary hypertension: guidelines for determining a pulmonary vasodilator response. Am Heart $f$ 1983; 105: $119-27$.

5 Shettigar UR, Hultgren HN, Specter M, Martin R, Davies DH. Primary pulmonary hypertension: favorable effect of isoproterenol. N Engl F Med 1976; 295: 1414-5.

6 Klinke WP, Gilbert JAL. Diazoxide in primary pulmonary hypertension. $N$ Engl $\mathcal{F}$ Med 1980; 302: 91-2.

7 Rubin LJ, Peter RH. Oral hydralazine therapy for primary pulmonary hypertension. $N$ Engl $f$ Med 1980; 302: 69-73.

8 Packer M, Greenberg B, Massie B, Dash H. Deleterious effects of hydralazine in patients with pulmonary hypertension. N Engl f Med 1982; 306: 1326-31.

9 Rubino JM, Schroeder JS. Diazoxide in treatment of primary pulmonary hypertension. $B r$ Heart $\mathcal{f}$ 1979; 42: 362-3.

10 Fleckenstein A. Specific pharmacology of calcium in myocardium, cardiac pacemakers, and vascular smooth 
muscle. Annu Rev Pharmacol Toxicol 1977; 17: 149-66.

11 Henry PD. Comparative pharmacology of calcium antagonists: nifedipine, verapamil and diltiazem. $A m \mathcal{F}$ Cardiol 1980; 46: 1047-58.

12 Antman E, Muller J, Goldberg S, et al. Nifedipine therapy for coronary artery spasm. $N$ Engl $\mathcal{F}$ Med 1980; 302: 1269-73.

13 Johnson SM, Mauritson DR, Willerson JT, Hillis LD. A controlled trial of verapamil for Prinzmetal's variant angina. N Engl f Med 1981; 304: 862-6.

14 Allen GS, Ahn HS, Preziosi TJ, et al. Cerebral arterial spasm-a controlled trial of nimodipine in patients with subarachnoid hemorrhage. $N$ Engl f Med 1983; 308: 619-24.

15 Rodeheffer RJ, Rommer JA, Wigley F, Smith CR. Controlled double blind trial of nifedipine in the treatment of Raynaud's phenomenon. $N$ Engl F Med 1983; 308: 880 3.

16 Brown BG, Pierce CD, Petersen RB, Singh BN, Bolson EL, Dodge HT. Verapamil: a mild epicardial coronary dilator, inhibits sympathetic and erogonovine-induced coronary constriction in humans [Abstract]. Circulation 1981; 64 (suppl IV): IV-150.

17 Young TE, Lundquist LJ, Chesler E, Weir EK. Comparative effects of nifedipine, verapamil, and diltiazem on experimental pulmonary hypertension. Am $\mathcal{f}$ Cardiol 1983; 51: 195-200.

18 Lippton HL, Nandiwada PA, Kadowitz PJ, Hyman AL. Vasodilator actions of nifedipine and verapamil in the pulmonary vascular bed [Abstract]. Fed Proc 1981; 40: 590.

19 Simonneau G, Escourrou P, Duroux P, Lockhart A. Inhibition of hypoxic pulmonary vasoconstriction by nifedipine. N Engl f Med 1981; 304: 1582-5.

20 Camerini F, Alberti E, Klugmann S, Salvi A. Primary pulmonary hypertension: effects of nifedipine. $\mathrm{Br}$ Heart f 1980; 44: 352-6.

21 Saito D, Haraoka S, Yoshida H, et al. Primary pulmonary hypertension improved by long-term oral administration of nifedipine. Am Heart $\mathcal{F}$ 1983; 105: 1041-2.

22 Wise JR Jr. Nifedipine in the treatment of primary pulmonary hypertension. Am Hear $f$ 1983; 105: 693-4.

23 De Feyter PJ, Kerkkamp HJJ, de Jong JP. Sustained beneficial effect of nifedipine in primary pulmonary hypertension. Am Heart $\mathcal{F}$ 1983; 105: 333-4.

24 Rubin LJ, Nicod P, Hillis LD, Firth BG. Treatment of primary pulmonary hypertension with nifedipine. A hemodynamic and scintigraphic evaluation. Ann Intern Med 1983; 99: 433-8.

25 McMurtry IF, Davidson AB, Reeves JT, Grover RF. Inhibition of hypoxic pulmonary vasoconstriction by calcium antagonists in isolated rat lungs. Circ Res 1976; 38: 99-104.

26 Tucker A, McMurtry IF, Grover RF, Reeves JT. Attentuation of hypoxic pulmonary vasoconstriction by verapamil in intact dogs. Proc Soc Exp Biol Med 1976; 151: 611-4.

27 Landmark K, Refsum AM, Simonsen S, Storstein O. Verapamil and pulmonary hypertension. Acta Med Scand 1978; 204: 299-302.

28 Ellrodt G, Chew CYC, Singh BN. Therapeutic implications of slow-channel blockade in cardiocirculatory disorders. Circulation 1980; 62: 669-79.

29 Lee TD Jr, Roveti GC, Ross RS. The hemodynamic effects of isoproterenol on pulmonary hypertension in man. Am Heart $\mathcal{F}$ 1963; 65: 361-7.

30 Elkayam U, Frishman WH, Yoran C, Strom J, Sonnenblick EH, Cohen MN. Unfavorable hemodynamic and clinical effects of isoproterenol in primary pulmonary hypertension. Cardiovasc Med 1978; 3: 1177-80.

31 Terry RW. Nifedipine therapy in angina pectoris: evaluation of safety and side effects. Am Heart f 1982; 104: 681-9.

32 Davidson A, McMurtry I, Reeves JT. Pulmonary vascular effects of verapamil. Am Heart f 1978; 95: 810-1.

33 Kentera D, Susic D, Zdravkovic M. Effects of verapamil and aspirin on experimental chronic hypoxic pulmonary hypertension and right ventricular hypertrophy in rats. Respiration 1979; 37: 192-6.

34 Fleckenstein A, Döring HJ, Kammermeier H. Einfluss von Beta-Receptorenblockern und verwandten Substanzen auf Erregung, Kontraktion und Energiestoffwechsel der Myokardfaser. Klin Wochenschr 1968; 46: 343-51.

35 Chew CYC, Hecht HS, Collett JT, McAllister RG, Singh $B N$. Influence of the severity of ventricular dysfunction on hemodynamic responses to intravenously administered verapamil in ischemic heart disease. Am $\mathcal{f}$ Cardiol 1981; 47: 917-22. 